\title{
PERAN PEREMPUAN DALAM PENDIDIKAN DI INDONESIA PADA ZAMAN MODERN
}

\author{
Syifa Evania Farin \\ Email: syifaevania13@gmail.com \\ Program Studi Pendidikan Ilmu Pengetahuan Sosial Fakultas Keguruan dan Ilmu \\ Pendidikan \\ Universitas Lambung Mangkurat \\ Banjarmasin
}

\begin{abstract}
Abstrak
Pada zaman sekarang atau biasa yang dikenal dengan zaman modern, merupakan zaman dengan keadaan yang serba praktis, serba cepat, instan, dan menggunakan alat-alat canggih. Hal ini pun juga terjadi pada dunia pendidikan yang ada di Indonesia pada saat ini. Perempuan memiliki peranan penting dalam pendidikan di Indonesia. Pada era modern kini harus dituntut serba canggih dan harus mengikuti perkembangan zaman. Teknologi pun sudah menjadi pelengkap dalam dunia pendidikan. Peran perempuan dalam hal ini sangat penting yaitu untuk mengarahkan para peserta didik nya agar tidak salah dalam memanfaatkan teknologi dalam dunia pendidikan, kenapa harus perempuan karena didalam sifat perempuan memiliki jiwa pantang menyerah dan penyabar. Teteapi pada kenyataannya peran perempuan dalam dunia pendidikan masih rendah.
\end{abstract}

\section{PENDAHULUAN}

Lembaga pendidikan merupakan tempat untuk menuntut ilmu, bahkan sebagian dari masyarakat melemparkan seluruhnya tanggung jawab kepada lembaga sekolah. Melihat dari perkembangan zaman teknologi terus berkembang, hal ini juga memiliki dampak pada dunia pendidikan, dalam hal pembelajaran banyak sekali yang berkembang, mulai dari menggunakan media elektronik dan perangkat digital lainnya. Hal ini juga yang menyebabkan para orang tua menyerahkan sepenuhnya tanggung jawab anak mereka kepada lembanga sekolah, dikarena kan mereka yang kebanayakan tidak terlalu mengerti tentang teknologi dan media pembelajaran yang menggunakan perangkat digital. Peristiwa ini yang menyebabkan para orang tua kewalahan dan takut tidak bisa mengiringi perkembangan teknologi dan tidak bisa mengajari anak-anak mereka, hal ini menjadi alasan 
mengapa para orang tua melemparkan penuh tanggung jawab mereka kepada pihak sekolah.

Pada zaman yang semakin canggih pada zaman yang sekarang ini, semua hal bisa dilakukan secara online dan serba instan. Seperti keperluan rumah tangga bahkan belanja pun bisa dilakukan mmenggunakan system online, bukan hanya itu saja dalam dunia pendidikan pun ikut terpengaruh dengan perkembangan zaman. Beberapa ahli mengatakan sudah banyak beberapa perubahan dalam proses pembelajaran peserta didik. Sekarang juga dikenal dengan sebutan "digital native" atau generasi digital, generasi ini lahir para era teknologi digital, yang biasanya tidak asing dengan penggunaan media elektronik. Dalam penggunaan teknologi digital ini tidak selalu memberi hal yang positif ada banyak dampak negative nya juga, beberapa diantaranya yaitu gangguan kesehatan fisik, terpapar konten negative, menimbulkan gangguan mental, terpapar hoax, mengganggu relasi, dan memicu kejahatan.

Tentunya dalam kondisi seperti ini memerlukan sosok peran dan pendamping agar peserta didik tidak salah dalam menggunakan media digital sebagai pembelajaran. Peran guru dan orang tua merupakan hal yang utama, karena jika peserta didik berada diwilayah sekolah maka yang mendampingi adalah guru dan jika peserta didik berada dirumah maka orang tua lah yang harus mendampingi dan mengawasi agar penggunaan media digital ini tidak salah dalam menggunakannya. Orang tua dan guru berperan dalam memperingati serta menanamkan batasan-batasan juga nilai moral dan rohaninya untuk menyaring dampak negative dari teknologi modern dan juga globalisasi.

Peran perempuan dalam pendidikan memiliki fungsi yang sangat penting. Pengetahuaan membuat perempuan cerdas dan semakin multi-tasking. Perempuan tidak hanya lagi menjalani rutinitas domestik seperti ibu rumah tangga dan pengasuh anak saja, melainkan ikut serta dalam memajukan dunia publik dan perkembangan pendidikan yang ada di Indonesia.

\section{DAMPAK POSITIF DAN NEGARIF MEDIA DIGITAL}

Pada masa sekarang ini teknologi sangat berkembang pesat, pada teknologi pembelajaran mengalami perkembangan terus menerus seiring dengan mengikuti perkembangan zaman. Yang paling sering digunakan atau mengalami perkembangan yang pesat biasanya disebut "cyber teaching" yaitu proses pembelajaran dimana cara pembelajarannya menggunakan internet. Atau istilah yang sering gunakan pada saat ini adalahh e-learning yaitu salah satu model pembeajaran yang menggunakan teknologi komunikasi dan informasi dengan internet.

Dalam teknologi pendidikan juga perlu memperhatikan beberapa indicator penting dan melibatkan presedur,ide,orang, organisasi, dan peralatan untuk menganalisis masalahmasalah yang ada. Maupun mencari jalan untuk mengatasi permasalahan, mengelola masalah tersebut yang menyangkut manusia AECT (Munir, 2008: 211). 
Internet ialah salah termasuk bagian dari alat komunikasi yang terjangkau dimana memungkinkan untuk terjadinya interaksi antara dua orang atau lebih. Keuntungan dari internet ini adalah memungkinkan seseorang untuk melakukan proses pembelajaran secara jarak jauh secara efektif dan efisien. Namun kita juga harus mengetahui bahwa teknologi ini tidak hanya mendatangkan hal yang positif saja tetapi juga bisa mendatangkan hal yang negative jika salah dalam menggunakannya.

Adapun dampak positif dari teknologi terhadap pendidikan adalah dengan hadirnya media elektronik dapat menjadi sumber ilmu dan pusat pencarian pengetahuan, hal ini dapat memudahkan para guru, sehingga peserta didik tidak hanya berpacu kepada materi yang disampaikan dari guru itu saja melainkan mereka bisa mencari sumber tambahan di internet, begitu juga dengan munculnya metode-metode baru yang memudahkan guru dan siswa dalam pembelajaran, dengan kemajuan teknologi ini munculah metode-metode baru yang membuat siswa memahami materi-materi yang abstrak dengan bantuan internet, mereka hanya perlu mencari apapun yang mereka ingin tahu dengan bantuan internet, kemudian dalam hitungan detik berbagai sumber pun muncul dan langsung bisa dibaca.

Adapun dampak negatif yang ditimbulkan dari teknologi dalam proses pendidikan adalah yaitu dengan munculnya E-learning dapat menyebabkan terciptanya individu yang bersifat individual atau menyendiri, sehingga memungkinkan etika dan disiplin peserta didik sulit untuk dijaga dan diawasi, lama kelamaan jika tidak diawasi etika peserta didik akan menurun. Dampak negatif lainnya yaitu dikhawatirkan peserta didik yang mengakses internet atau menggunakan teknologi tidak memanfaatkannya dengan baik dan optimal, tetapi malah mengakses diluar dari kebutuhan pendidikan, seperti game, pornografi, dll. Bahkan memungkinkan peserta didik menjadi pecandu dari adanya dunia maya secara berlebihan. Juga dapat menyebabkan sikap apatis pada peserta didik, bak itu pelajar maupun yang mengajarnya. Hal ini dapat kita lihat dari penggunaan e-learning, dimana system pembelajaran ini tidak melaksanakan pembelajarannya secara tatap muka, maka dampaknya adalah peserta didik kurang aktif dan tidak maksimal dalam system pembelajaran (Asmani, 2011:149). Untuk itu perlu adanya pengawasan dan dampingan khusus agar penggunaan media digital digunakan dengan baik sebagaimana mestinya. Dan harus menyeimbangkan dengan baik agar penggunaannya lebih efektif.

\section{PERAN PEREMPUAN DALAM PEDIDIKAN}

Berkaitan dengan perkembangan zaman yang semakin waktu terus mengalami perubahan, masyarakat sekarang membutuhkan peran perempuan disegala aspek, baik itu sosial ekonomi ataupun pendidikan. Hal ini disebabkan karena adanya tuntutan bangsabangsa dan atas masyarakat global bahwa adanya kemajuan suatu bangsa ditentukan dari bagaimana bangsa tersebut memperlakukan perempuan, peduli dan memeri akses yang seluas-luasnya bagi perempuan untuk beraktifitas dan ikut membangun bangsa. 
Di Indonesia sendiri pembagian kerja antra laki-laki maupun perempuan sangat menggambarkan peran perempuan. Tujuan awal dari pembagian kerja menurut jenis kelamin ini sangat tidak diragukan lagi, hal ini berkaitan dengan keberadaan antara peran laki-laki dan peran perempuan. Umumnya setiap manusia termasuk perempuan tumbuh dan besar dari bekal yang dibawa dan diberikan oleh masyarakat, bekal yang dibawa berupa budaya,nilai,hukum,norma, dan lainya. Di Indonesia, kepedulian terhadap eksistensi dengan perempuan adalah dengan adanya interuksi dari Presiden RI yaitu No. 9 Tahun 2000 mengenai "Pengarusutamaan Gender dalam Pembangunan Nasional". Tujuan dan strategi pengarusutamaan gender (PUG) adalah agar mencapai kesetaraan dan keadilan gender, dengan melalui kebijakan dan program yang melihat dari pengalaman, kebutuhan, aspirasi, dan permasalahan perempuan maupun laki-laki dalam kebijakan di berbagai bidang kehidupan dan pembangunan. Di Indonesia sendiri pada beberapa decade terakhir ini telah muncul sebuah kesadaran baru tentang pentingnya emansipasi dari perempuan, dalam cabinet pemerintah pun terdapat menteri yang memiliki tugas khusus dalam membidangi peranan perempuan, bahkan sejak pemerintahan Orde Baru. Hal ini menandakan peran penting perempuan dalam berbagai bidang, ditengah pemasalahan sosial, politik, ekonomim dan pendidikan.

Dalam permasalahan dan banyak perbincangan public pada era modern saat ini ternyata perjuangan persamaan gender yang telah lama disuarakan, secara kenyataaannya menunjukan mengenai peran perempuan dalam perspektif persamaan hak dan kedudungan dengan lalaki telah semakin maju dan berkembang pesat. Hal ini muncul dan didasari karena adanya kesadaran dari para perempuan itu sendiri mengenai arti penting pendidikan bagi masa depan umat manusia khususnya perempuan, baik itu dalam menghadapi persaingan kerja dan karir yang sama dengan laki-laki.

Dalam dunia pendidikan perempuan memiliki peran yang sangat penting. Banyak orang yang memiliki persepsi bahwa dalam dunia pengetahuan adalah milik kaum adam. Seolah kaum wanita tidak memiliki peran apa-apa dalam bidang ilmu pengetahuan. Padahal yang kita tahu melihat dari sejarah banyak sekali wanita yang berperan penting dalam pegembangan ilmu pengetahuan. Karena pada dasarnya definisi pendidikan adalah suatu usaha yang dilakukan oleh individu-individu baik itu laki-laki maupun perempuan untuk melaksanakan nilai-nilai, kebiasaan-kebiasaa, serta bentuk ideal kehidupan dalam melaksanan kehidupan yang lebih efektif (Wahab, 2007).

Pada zaman modern sekarang ini kemajuan teknologi semakin pesat berkembang seiring berjalannya waktu, pada perkembangan tekologi di dunia pendidikan juga memiliki dampak baik itu negatif maupun positifnya. Untuk itu perlu adanya pengawasan khusus agar pemanfaatan dan kegunaan dari teknologi ini dapat digunakan secara efektif. Perempuan memiliki peran yang sangat penting. Bukan hanya diwajibkan untuk menjadi seorang ibu perempuan juga bisa bekerja, tidak sedikit perempuan yang mengambil dua profesi yaitu sebagai ibu rumah tangga dan perkerjaan yang lain. Tujuan dari pendidikan 
yang baik ialah usaha sadar dan terencana untuk mewujudkan suasana belajar dan proses pembelajaran agar peserta didik secara aktif mengembangkan potensi dirinya agar mempunyai kekuatan spiritual keagamaan, kepribadian, pengendalian diri, kecerdasan, akhlak mulia serta keterempilan yang diperlukan dirinya, dan masyarakat bangsa dan Negara. Untuk itu peran perempuan dalam dunia pendidikan.

Perempuan dalam sebuah keluarga memiliki peran dan tanggung jawab yang tidak mudah. Selain tugas mereka harus menyiapkan diri agar bisa bekerja untuk memenuhi kebutuhan hidupnya, mengikuti tanggung jawab lain beruba tanggung jawab punuh atas anak-anak mereka baik itu jasmani, kasih sayang serta tidak kalah pentingnya yaitu memenuhi kebutuhan akan penddidikan anak-anaknya. Pemenuhan atas pendidikan anak tidak hanya sekedar memberikan anak kesempatan untuk belajar serta disekolahkan melainkan peran perempuan dalam pendidikan dalam keluarga secara garis besar yaitu perempuan sebagai pendidik, bagaimanapun kesebukan perempuan pendidikan tidak boleh dilupakan. Selain itu juga perempuan juga sebagai pelindung dan pemelihara, perempuan ialah sebagai dasar dari pendidikan anak. Salah satu tugas nya itu membuat anak lebih dewasa dan mandiri, juga mngajarkan kepada anak mana yang baik dan mana yang salah, agar dalam keadaan zaman yang semakin berkembang pun si anak tetap dapat memilah mana yang baik mana yang salah.

Begitu pentingnya perkembangan partisipasi dari perempuan terhadap perkembangan dunia pendidikan, dan juga peningkatan pengetahuan bagi kelompok masyarakat kaum wanita, karena perempuan (Ibu) ialah "sekolah" bagi anak-anak mereka. Pendidik yang paling pertama dan utama dalam kerluarga, bahkan perempuan dapat menjadi indicator kekuatan seuatu bangsa. Perempuan tidak hanya peduli terharap dirinya saja, tapi juga pada anak-anaknya. Tuntutan perkembangan zaman dan teknologi membuat perempuan lebih bertindak kreatif dan inovatif untuk mempertahankan pendidikan di Indonesia agar menjadi efektif meskipun dengan adanya perkembangan zaman.

\section{SIMPULAN}

Pada zaman yang semakin canggih pada zaman yang sekarang ini, semua hal bisa dilakukan secara online dan serba instan. Seperti keperluan rumah tangga bahkan belanja pun bisa dilakukan mmenggunakan system online, bukan hanya itu saja dalam dunia pendidikan pun ikut terpengaruh dengan perkembangan zaman. Beberapa ahli mengatakan sudah banyak beberapa perubahan dalam proses pembelajaran peserta didik. Sekarang juga dikenal dengan sebutan "digital native" atau generasi digital, generasi ini lahir para era teknologi digital, yang biasanya sangat tidak asing dengan penggunaan media elektronik. Dalam penggunaan teknologi digital ini tidak selalu memberi hal yang positif ada banyak dampak negative nya juga, beberapa diantaranya yaitu gangguan kesehatan fisik, terpapar konten negative, menimbulkan gangguan mental, terpapar hoax, mengganggu relasi, dan memicu kejahatan. 
Untuk itu perlu adanya pengawasan khusus agar pemanfaatan dan kegunaan dari teknologi ini dapat digunakan secara efektif. Perempuan memiliki peran yang sangat penting. Bukan hanya diwajibkan untuk menjadi seorang ibu perempuan juga bisa bekerja, tidak sedikit perempuan yang mengambil dua profesi yaitu sebagai ibu rumah tangga dan perkerjaan yang lain. Tujuan dari pendidikan yang baik ialah usaha sadar dan terencana untuk mewujudkan suasana belajar dan proses pembelajaran agar peserta didik secara aktif mengembangkan potensi dirinya agar mempunyai kekuatan spiritual keagamaan, kepribadian, pengendalian diri, kecerdasan, akhlak mulia serta keterempilan yang diperlukan dirinya, dan masyarakat bangsa dan Negara. Tuntutan perkembangan zaman dan teknologi membuat perempuan lebih bertindak kreatif dan inovatif untuk mempertahankan pendidikan di Indonesia agar menjadi efektif meskipun dengan adanya perkembangan zaman.

\section{REFERENSI}

Abidin, Z. (2017). Kesetaraan gender dan emansipasi perempuan dalam pendidikan Islam. Tarbawiyah: Jurnal Ilmiah Pendidikan, 12(01), 1-17.

Efendi, I., Prawitasari, M., \& Susanto, H. (2021). Implementasi Penilaian Pembelajaran Pada Kurikulum 2013 Mata Pelajaran Sejarah. Prabayaksa: Journal of History Education, 1(1), 21-25.

Indah, I. (2013). Peran-peran perempuan dalam masyarakat. Academica, 5(2).

Jamun, Y. M. (2018). Dampak teknologi terhadap pendidikan. Jurnal Pendidikan dan Kebudayaan Missio, 10(1), 48-52.

Khayati, E. Z. (2008). Pendidikan dan independensi perempuan. Musawa Jurnal Studi Gender dan Islam, 6(1), 19-35.

Syamsiyah, D. (2015). Perempuan dalam Tantangan Pendidikan Global: Kontribusi Kaum Perempuan dalam Mewujudkan Millenium Development Goals. PALASTREN Jurnal Studi Gender, 8(2), 225-242.

Susanto, H. (2020). Profesi Keguruan. Banjarmasin: ULM

Susanto, H., dan Akmal, H. (2018). Efektivitas Penggunaan Aplikasi Pembelajaran Berbasis Mobile Smartphone Sebagai Media Pengenalan Sejarah Lokal Masa Revolusi Fisik Di Kalimantan Selatan Pada Siswa Sekolah Menengah Atas. HISTORIA: Jurnal Program Studi Pendidikan Sejarah, 6(2), 197-206. ULM 